\title{
Current Income Tax Disclosures in Separate Financial Statements of IFRS Adopters in Slovakia ${ }^{\#}$
}

\author{
Miloš Tumpach ${ }^{*}-$ Adriana Stanková ${ }^{* *}$
}

\section{Introduction}

Among the various prerequisites for the accession process, there is one that calls any prospective member state of the EU to closely review and (if necessary) amend its legislation before entering the community. In Slovakia in 2002, this process led (inter alia) to promulgation of new Act on Accounting (No. 431/2002 Coll. of Laws). In its paragraph 17, the law permitted the use of by stating that: "Okrem účtovnej závierky zostavenej podl'a tohto zákona môže účtovná jednotka poskytovat' účtovné záznamy obsahujúce informácie, ktoré sú zostavené podla medzinárodných účtovných štandardov, ktoré vydáva Rada pre medzinárodné účtovné štandardy so sidlom $v$ Londýne, alebo iných uznávaných účtovných zásad”. In plain English: "Apart for \{alternative meaning: ,except for" financial statements \{to be\} prepared in accordance with this law, the entity is free to provide accounting records compiled in accordance with international accounting standards which are published by the International Accounting Standards Board with its seat in London \{alternative translation " Rada pre medzinárodné účtovné štandardy with

\# The article is processed as an output of a research project E-learning ako forma univerzitného a celoživotného vzdelávania $v$ oblasti účtovníctva registered by the Kultúrná edukačná a grantová agentúra under the registration number 023EU-4/2012. This article has been also prepared under the research project Assumptions for Introduction of the IFRS as an Alternative Tax Base in a Small Open Economy: Evaluation of Its Impact on Country's Competitiveness supported by the Czech Science Foundation under the registration number P403/12/1901.

doc. Ing. Miloš Tumpach, PhD. - head of the Department of Accounting and Auditing; University of Economics in Bratislava, Dolnozemská cesta 1, 85235 Bratislava, Slovakia, <tumpach@euba.sk>.

** Ing. Adriana Stanková - Ph.D. student; University of Economics in Bratislava, Dolnozemská cesta 1, 85235 Bratislava, Slovakia, <adriana.stankova@euba.sk>. 
its seat in London" or "Rada pre medzinárodné účtovné štandardy so sidlom v Londýne ") or with reference to other recognized accounting principles."

The ambiguity of the text clearly created a set of problems here. At first, nobody was able to determine whether the financial statements can (apart for) or must not (except for) be prepared in accordance with the international accounting standards. In addition, the text seemed to propose the use of international accounting standards for accounting records in addition (rather than instead) of accounting records necessary for preparation of financial statements in accordance with the national accounting rules. And finally, the text has referred to the translated rather than legal name of the International Accounting Standards Board. Consequently, there was a risk of establishing a new body (with a translated name), which would have nothing in common with IASB, but would still have an authority to promulgate accounting standards for Slovak entities.

Apparently, those doubts were also shared by various influential stakeholders and as a result, the law was accordingly amended in 2004. New paragraph (17a) stated in a more precise wording that: Apart from the entities which are regulated by the specific regulation there is a footnote which refers to IFRSs as approved by the EU\}, the separate financial statements need to be prepared with reference to specific regulation \{again, the footnote refers to IFRSs\} by ... banks ... insurance companies ... businesses which two of the following three quantitative criteria \{assets over 5000000 Slovak crowns, turnover over 5000000 , more than 2000 employees\}" In order to decrease overall financial burden for respective companies, the Act on Income Taxes has been changed the following year (2005). However, even after 9 years, there are serious concerns whether this change had, have or will achieve any of its purported goals. Following the prior research in other countries (e. g. Stromsem (2009), Rood and Kinney (2008) and McGowan, J. R. and Wertheimer, M. (2009) for USA, Karampinis and Hevas (2013) for Greece, Geyer, (2013) for Ukraine and Eberhartinger and Klostermann (2007) for Austria and Germany), or Haverals (2007) for Belgium, we have focus our paper on income tax implications arising from adoption of IFRSs in Slovakia as well. Contrary to the previous studies, our attention will be devoted to quality of current income tax disclosures rather than on quantitative analysis of financial data presented in the separate financial statements. 


\section{Rules for taxation of IFRS adopters in Slovakia}

According to Act on Accounting, several entities governed by the Slovak laws are unconditionally required to compile their separate financial statements in accordance with the IFRSs as adopted by the European Union, e. g. National Bank of Slovakia, various types of investment and fiduciary companies, banks (including branches of foreign banks), (re)insurance companies (except for the health insurance companies) and Railway Company of the Slovak Republic. Other entities have to follow the IFRSs provided that their meet at least two of three criteria for at least two consecutive years (value of the assets exceeds $170000000 €$, turnover is over $170000000 €$, there are more than 2000 employees). In addition, few entities can decide to comply either with IFRSs or with national accounting regulation (e. g. traders with securities, issuers of securities which are traded at the regulated market within the EU, payment institutions), provided that they are not falling in any of the previous two categories described above.

Because in Slovakia there is not full compliance between accounting and tax concepts of income and expenses, for the tax purposes accounting figures need to be thoroughly reconciled in the process of preparation of tax fillings. Still, similarly to other countries (Pezzotta and Passardi, 2010; Chan et al., 2010) accounting records could be considered to be a starting point of this process. As a result, many of the amendments of income tax laws could not only by attributed, but were in fact historically driven by major changes in accounting legislation. Following the adoption of the IFRSs as a reference base for the preparation of separate financial statements, several countries including Italy (Giacometti, 2009) and Slovakia have opted for use of its results as a starting point for determination of income taxes as well. Consequently, such countries have also issued reconciliation regulations for transformation of accounting profit (determined with reference to IFRSs) to tax base.

In Slovakia, paragraph 17 of the Act on Income Taxes requires that companies, which are legally preparing their statutory separate finance statements in accordance with IFRSs, need to determine their tax profit by adjusting the very IFRS profit. The tax law provides such taxpayers with an option to carry out such adjustment in one of two following ways: 
- $\quad$ either to reconcile the IFRS profit to adjusted profit following a procedure promulgated by a regulation of the Ministry of Finance;

- or to reconcile the IFRSs based profit or loss to adjusted profit which would be determined provided that the company were used double-entry accounting system (sic!).

In both cases, resulting adjusted profit need to be further transformed into tax base.

In order to fulfil the requirements of first option, the Ministry of Finance has in 2009 published its regulation "Opatrenie Ministerstva financií Slovenskej republiky z 15. februára 2006, ktorým sa ustanovuje spôsob úpravy výsledku hospodárenia vykázaného daňovníkom v individuálnej účtovnej závierke podl'a medzinárodných štandardov pre finančné výkaznictvo MF/011053/2006-72" with an apparent intention to turn of IFRS profit into "more realistic and tangible figures upon which the tax could be determined" profit. This was and still is rather a challenge, considering the length of the regulation (altogether 5 pages) and its ambiguous text. For example, paragraph 11 contains following adjustment: " $\{I F R S\}$ profit shall be increased by the amounts, which were, or will be considered as tax expenses and decreased by the amounts which were, or will be considered as tax income ...". Thus, profit of the selected accounting period would be adjusted by the respective amounts recorded in any of past periods, not to mention reference to unpredictable amounts in future periods! As a result, the regulation has been amended the same year, even before its effective date, by three (sic!) additional pages.

Also, one can also clearly see the problems with the second option, as tax law is referring to general double entry accounting system, rather than to national system of double entry accounting for business entities. As an unintended consequence of this "Freudian slip" companies could directly transform their IFRS figures into tax base without any need for its prior adjustment. Although this option is supressed by the form of the income tax fillings (as here the reference to national double entry accounting is presented as the only option - without taking into consideration some other of different systems), the companies could legally enforce their rights, considering the precedence of the option given by the law over the by-laws or administrative measures. 


\section{Data and Methodology}

As a consequence of ambiguity of legal guidelines for transformation of IFRS profit into tax base, it seems to be inevitable that stakeholders of the company need to know the way of how the current income taxes have been derived from IFRS profit. Unless the current income taxes are immaterial, lack of such information make it almost impossible to make reliable projections of the future financial position and performance of the company. Prior study (Bielčík, 2009), showed that only $19 \%$ of 141 Slovak IFRS adopters were using this regulation, while remaining $81 \%$ opt to reconcile the IFRS profit to profit which would be determined in accordance with national accounting regulation. The results might be distorted by the practice of bank, for which there is not any national accounting regulation and therefore are forced to apply the said regulation.

We became aware that even though we highly appreciate the study, it cannot be used for assessment of quality of disclosures. The reason was, that the study was based on information from the questionnaires (which are private in their nature) rather than on information publicly available in the separate financial statements of IFRS adopters. Hence we decide to make a follow-up of this study, this time based on data disclosed in the notes of said companies.

In order to evaluate the comprehensiveness of related disclosures, we started with the identification of such IFRS adopters. However, neither its number nor their identity has been officially confirmed therefore it can only be estimated (Farkaš, 2013) and determined indirectly. In order to do so, we have retrieved and analysed data from the electronic form of the Bulletin of the Business Register, containing (inter alia) selected financial data for all statutory audited companies. Because any separate financial statements legally prepared in accordance with IFRSs need to be audited in Slovakia, it is reasonable to assume, that the names of IFRS adopters are included in this data set. As a result, we were able to extract names and identification numbers of 143 IFRS adopters (for the year 2012) a number that is fairly closely to number used in Bielčík's study. Out of this number, we have randomly selected 80 , the data, which were further analysed.

Since beginning of 2014, the electronic Bulletin of Business Register has been replaced with more comprehensive Registry of Financial 
Statements (RFS). RFS allows retrieving financial statements of almost any company in Slovakia, but it has one significant drawback - there is no feature, which will provide a list of IFRS adopters upon request. In order to cope with this problem, we retrieved the notes to separate the financial statements for 2013 based on the list compiled from the electronic form of the Bulletin Business Register (reflecting the situation in 2012). We are convinced that even though there is a time shift between both sets of data, it will only have a minor impact on the reliability of the study, if any.

Content of the resulting data was further analysed. At first, we were looking for comments providing detailed explanation of how the current income tax has been determined in the first stage (that is, before the adjustment for any differences between accounting and tax income and expenses). Specifically, we have been searching for any explicit statement of the use of the regulation of the Ministry of Finance, direct adjustment of the IFRS profit, or adjustment of IFRS profit to profit which would be determined provided that the national accounting standards would have been applied).

Consistently with the assumptions promulgated by the Accounting Standards Board (2010), we have additionally searched for the evidence of "boilerplate disclosures" (examples include, but are not limited to, unnecessary identical text of sentences or comments provided by the different entities in the same parts of the financial statements). In this regard, we have been focusing on the occurrence of the terms "precedence" and "interpretation judgements" which are rarely used in common language. Because of their rare occurrence, their existence in the financial statements of different companies could be considered as an evidence of such disclosure practice.

\section{Results and Discussion}

Even though the analysis has been made on a limited sample of 80 IFRS adopters (out of 143 identified), it has certain representative value. As of the end of October 2013, thirty-two entities (40.00\%) have filled their financial statements for the year 2013 to the Register of Financial Statements. By law, financial statements need to be orderly provided within the 6 months after the balance sheet date (there are some entities though, which are using financial, rather than calendar year as their 
accounting period). Out of this number, 18 (or $56.25 \%$ out of 32 entities) are represented by insurance companies and banks.

From remaining 48 entities $(60.00 \%$ of the overall sample of 80 entities) only 4 are providing useful information about the way of how the adjusted profit (which would be further reconciled to tax base) is determined. Three of them are adjusting IFRS profit to profit, which were determined to provide that these entities would be using national rather than international accounting standards. Only one claims that it is using reconciliation regulation of the Ministry of Finance. For remaining fortyfour entities $(55.00 \%)$, determination of current income taxes is either not addressed in their separate financial statements or is addressed in imperfect and rather general way (e. g. "profit is adjusted in accordance with the applicable law"). Surprisingly, all of these companies are providing rather detailed information about the deferred income taxes.

And there was additional surprising information. For more than $17 \%$ of Slovak IFRS adopters we were able to find an evidence of boilerplate disclosures, as 18 of them contain same terms "precedence" and "interpretation judgments". Because these terms occur very rarely in the common language (not to mention their occurrence in the same sentence as was the case of 18 IFRS adopters) we consider this to be a proof of the mock, rather than sincere, disclosures.

\section{Conclusion}

Based on a sample of 80 Slovak IFRS adopters we can see, that the disclosures on the relation between IFRS profit and the current income taxes are quite unsatisfactory. For majority of them, information is either missing or omitted or presented in a way which prohibits the users to make any projections on the impact of change in national accounting standards (or any other reference framework) on taxable profit of the said companies. Even more, a significant portion of the adopters is using boilerplate disclosures, which further contributes to the failure of the separate financial statements to convey meaningful, relevant and reliable information. We can see the opportunities to improve the way of reporting information related to current taxes - to (at least) achieve the level of how the information of the deferred taxes is currently presented by the very same companies. 


\section{References}

Accounting Standards Board (2010): Financial Capital Management Disclosures. Retrieved October 11, 2014 from: https://frc.org.uk/OurWork/Publications/ASB/Financial-Capital-Managment-Disclosures.pdf

Act of Accounting No. 431/2002 Coll. of Laws.

Bielčík, M. (2009): Analýza prístupu $k$ výpočtu dane z príjmov $u$ subjektov s povinnostou prípravy individuálnej účtovnej závierky podl'a IFRS. Retrieved July 01, 2014, from http://www.profini.sk/analyzapristupu-k-vypoctu-dane-z-prijmov-u-subjektov-s-povinnostou-pripravyindividualnej-uctovnej-zavierky-podla-ifrs/

Chan, K. H. - Lin Kenny Z. K. Z. - Mo, P. L. L. (2010): Will a departure from tax-based accounting encourage tax noncompliance? Archival evidence from a transition economy. Journal of Accounting and Economics, vol. 50, no. 1, pp. 58-73.

Eberhartinger, E., - Klostermann, M. (2007): What if IFRS were a Tax Base? New Empirical Evidence from an Austrian Perspective. Accounting in Europe, vol. 4, no. 2, pp. 141-168.

Farkaš, R. (2013): Účtovná závierka obchodných spoločností v Slovenskej republike. Bratislava: Wolters Kluwer. ISBN 9788080785581.

Geyer, E. S. (2013): Accounting Reform in Ukraine: International Standards and the Tax Consequences. International Journal of Academic Research, vol. 5, no. 5, pp. 296-298.

Giacometti, P. (2009): Italy implements provisions for the tax treatment of IFRS adopters. International Tax Review, vol. 20, no. 5, pp. 59.

Haverals, J. (2007): IAS/IFRS in Belgium: Quantitative analysis of the impact on the tax burden of companies. Journal of International Accounting, Auditing and Taxation, vol. 16, no. 1, pp. 69-89.

Karampinis, N. I., - Hevas, D. L. (2013): Effects of IFRS adoption on taxinduced incentives for financial earnings management: Evidence from Greece. International Journal of Accounting, vol. 48, no. 2, pp. 218-247.

McGowan, J. R. - Wertheimer, M. (2009): The Effect of IFRS Implementation on Tax. Tax Adviser, vol. 40, no. 12, pp. 842.

Pezzotta, D. - Passardi, M. (2010): Besteuerung aufgrund IFRSAbschlüssen - Utopie oder Wirklichkeit? IRZ, Heft 4, 2010, pp. 113-120. 
Tumpach M. - Stanková A.: Current Income Tax Disclosures in Separate Financial Statements of IFRS Adopters in Slovakia.

Rood, J. L. - Kinney, L. (2008): IFRS Implications for Income Taxes. Financial Executive, vol. 24, no. 8, pp. 52-54.

Stromsem, W. R. (2009): IFRS and Your Tax Practice. Tax Adviser, vol. 40, no. 5, pp. 322-323. 


\title{
Current Income Tax Disclosures in Separate Financial Statements of IFRS Adopters in Slovakia
}

\begin{abstract}
As a direct result of the accession into EU, IFRSs have been introduced in Slovakia as a framework for compilation of separate financial statements of various businesses since 2006. Because of traditionally strong ties between accounting and tax regulation, taxpayers and tax authorities were exposed to an unprecedented situation. Consequently, national parliament and the government have tried to address major identified issues. Apparently, two underlying principles have been established for carrying out these initiatives - to comply with the Regulation No. 1606/2002 and to keep the tax burden at the same level. Still, there is serious concern about the effectiveness of the measures adopted, as there are at least three approaches for determination of income taxes of IFRS adopters in Slovakia. Because the relevance of accounting information is partially driven by their ability to predict future order and results of events, our paper is focused on the assessment of the disclosures related to current income tax determination, presented in the separate financial statements of the said companies. Though lack of such information decrease the relevance of financial statements, it is quite commonplace. Additionally, we have found traces of boilerplate disclosures (i. e. likely wordings presented in financial statements of different companies).
\end{abstract}

Key words: IFRS; Taxation; Slovakia.

JEL classification: M41, M48, H25 